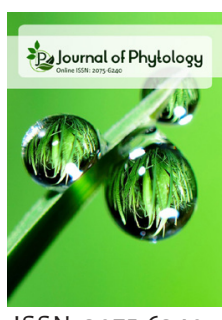

ISSN: $2075-6240$

\title{
Effect of the temperature and relative humidity in stored sotol (Dasylirion cedrosanum Trel.) seeds on fungi biodiversity
}

\author{
A. Antonio-Bautista', M. E. Vazquez-Badillo', Ma. E. Galindo-Cepeda², \\ A. Flores-Naveda', E. Benítez-Neri', A. Sánchez-Arizpe², J. L. Arispe-Vázquez ${ }^{2 *}$ \\ 'Departamento de Fitomejoramiento, Universidad Autónoma Agraria Antonio Narro, Antonio Narro \#1923, C.P. \\ 25315, Buenavista, Saltillo, Coahuila, México, 'Departamento de Parasitología Agrícola, Universidad Autónoma \\ Agraria Antonio Narro, Antonio Narro \#1923, C.P. 25315, Buenavista, Saltillo, Coahuila, México
}

Received: November 25, 2020 Revised: February 12, 2021 Accepted: February 15, 2021 Published: March 16, 2021

*Corresponding Author: J. L. Arispe-Vázquez, Email: arispe_uaaan@ hotmail.com

\section{ABSTRACT}

The objective of the research was to identify the fungi in sotol seeds at different conditions of temperature and relative humidity. Seed were collected at Buñuelos, municipality, and taken to the Laboratory of the Center for Training and Development in Seed Technology (CCDTS) at Universidad Autonoma Agraria Antonio Narro. Seed was stored for a period of 90 days, whit conditions of $60,75,80$ and $85 \%$ of relative humidity kept at 5,15 and $25^{\circ} \mathrm{C}$. Fungi identifying by morphological criteria. A completely randomized experimental using $\mathrm{R}$ software with factorial arrangement whit two replications. Pathogens identified were: Aspergillus glaucus, Aspergillus niger, Fusarium sp., Penicillium sp., Aspergillus candidus, Cladosporium sp., Alternaria sp. and Aspergillus ochraceus. The results showed that the higher the humidity, temperature, storage time and the incidence of fungi tends to be higher. Fungi with higher presence in sotol seeds were: Aspergillus glaucus and Penicillium sp. Safe storage environments for sotol seeds reported in this work are $5^{\circ} \mathrm{C}$ and a relative humidity of $60-75 \%$. Sotol seeds tolerates conditions of $15^{\circ} \mathrm{C}$ and a relative humidity up to $75 \%$.

KEYWORDS: Seed, Environment, Conditions, Incidence

\section{INTRODUCTION}

A sotol (Dasylirion cerdrosanum Trel.) is an integral part of human history in northern Mexico and southern United States (Valdés et al., 2012). In Mexico the plants can be found in the Sierra Madre Occidental and Sierra Madre Oriental mountain range systems; mainly in the states of Chihuahua, Coahuila and Durango. Sotol is an important ecological component of desertic zones, since it contributes to soil maintenance while being a food source for some of the desertic fauna, particularly rodents and birds (Reyez et al., 2012). Seeds are considered the most important germplasm source for mass production of plants (Poehlman, 2005). The storage conditions of seeds is highly important (Amaral \& Lemos, 2009; Oyekale et al., 2012), mainly due to pathogens potentially being transported within the seeds, surviving in it for long periods of time (Mercado, 2018). Species Aspergillus, Penicillium, Fusarium, Rhizopus and Alternaria were commonly found in post-harvest storage conditions as mold (Chavan, 2011). In order to carry out an adequate storage of seeds, is necessary to minimize viability loss; factors that influence this during the storage are: humidity content of the seeds, relative humidity and temperature of the environment temperature, as well as biotic factors presented, such as the incidence of fungi and insect pests. Therefore, it is important to identify the species of fungi in stored maize grains with special emphasis on mycotoxigenic species, which pose a potential risk to human and animal health (Castlellarie et al., 2010). Regarding the above mentioned, the aim of this research was to identify the different fungi present in the seeds of sotol (D. cedrodanum) stored in twelve different environmental conditions.

\section{MATERIAL AND METHODS}

\section{Biological Material Used}

Sotol seeds collected in 2016 at Buñuelos, municipality, Saltillo, Coahuila, Mexico, whose coordinates are 2527'36.1”N $101^{\circ} 01^{\prime 2} 21.0^{\prime \prime W}$ (Figure 1). 


\section{Storage Time and Conditions}

Sotol seeds were stored for a 90-day period under relative humidity conditions of $60,75,80$ and $85 \%$ and kept at 5, 15 and $25^{\circ} \mathrm{C}$, respectively. To achieve the $60 \%$ of relative humidity in the storage conditions, a saturated solution of glucose was used. Similarly, for the $75 \%$ of relative humidity a sodium chloride $(\mathrm{NaCl})$ solution was used; while for the $80 \%$ and $85 \%$ an ammonium sulfate $\left[\left(\mathrm{NH}_{4}\right)_{2} \mathrm{SO}_{4}\right]$ and potassium chloride solutions were used, respectively (Winston \& Bates, 1960). Two hundred forty experimental units were placed in perforated cloth meshes and were randomly distributed in the plastic chambers that made up each of the warehouse environments. Sampling was carried out at $0,15,30,60$ and 90 days, each with two replications (Table 1).

\section{Isolation, Identification and Incidence of Fungi Pathogens}

Ten seeds were placed equidistant by Petri dish with MSA culture medium (two replications) and kept at $25^{\circ} \mathrm{C} \pm 2{ }^{\circ} \mathrm{C}$ for $192 \mathrm{~h}$. Identification of pathogens was made in a compound microscope following Moreno keys (Moreno, 1988). The results

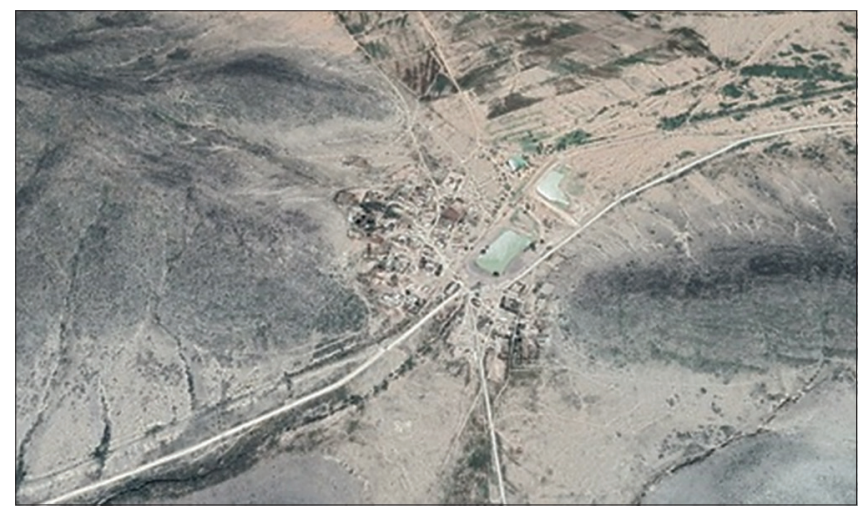

Figure 1: Buñuelos, Saltillo, Coahuila, Mexico were reported in percentage using the formula (Abdullah \& AlMousawi, 2010): Porcentaje incidence $\%=$ number of seeds on which fungi appeared/ total number of seeds $\times 100$

\section{Analysis of results}

Data collected was evaluated completely randomized in a factorial arrangement of two factors, where: factor A for ambient and factor $\mathrm{B}$ for evaluation times. The comparison of means using Tukey test $(\mathrm{p}=0.05)$. Results were analyzed through the R software (R Core Team, 2013).

\section{RESULTS}

Figure 2 shows the behavior of the incidence of pathogens according the environments $(\mathrm{p}=0.001)$, and a higher incidence presented in the environments 11 and 12 , with 46 and $36 \%$. The lowest incidences are present in the environments: 7, 2 and 4 with $1.0,4.0$ and $5.0 \%$, respectively.

Figure 3 shows the difference in incidence in the sampling; in first sampling, there was no incidence of pathogens $(p=0.001)$, in second sampling at 15 days with $7 \%$, the third sampling at 30 days with $9.5 \%$, the fourth sampling at 60 days

Table 1: Study environments

\begin{tabular}{lcc}
\hline Environments & Temperature $\left({ }^{\circ} \mathrm{C}\right)$ & Relative humidity $(\%)$ \\
\hline 1 & 5 & 60 \\
2 & 5 & 75 \\
3 & 5 & 80 \\
4 & 5 & 85 \\
5 & 15 & 60 \\
6 & 15 & 75 \\
7 & 15 & 80 \\
8 & 15 & 85 \\
9 & 25 & 60 \\
10 & 25 & 75 \\
11 & 25 & 80 \\
12 & 25 & 85 \\
\hline
\end{tabular}

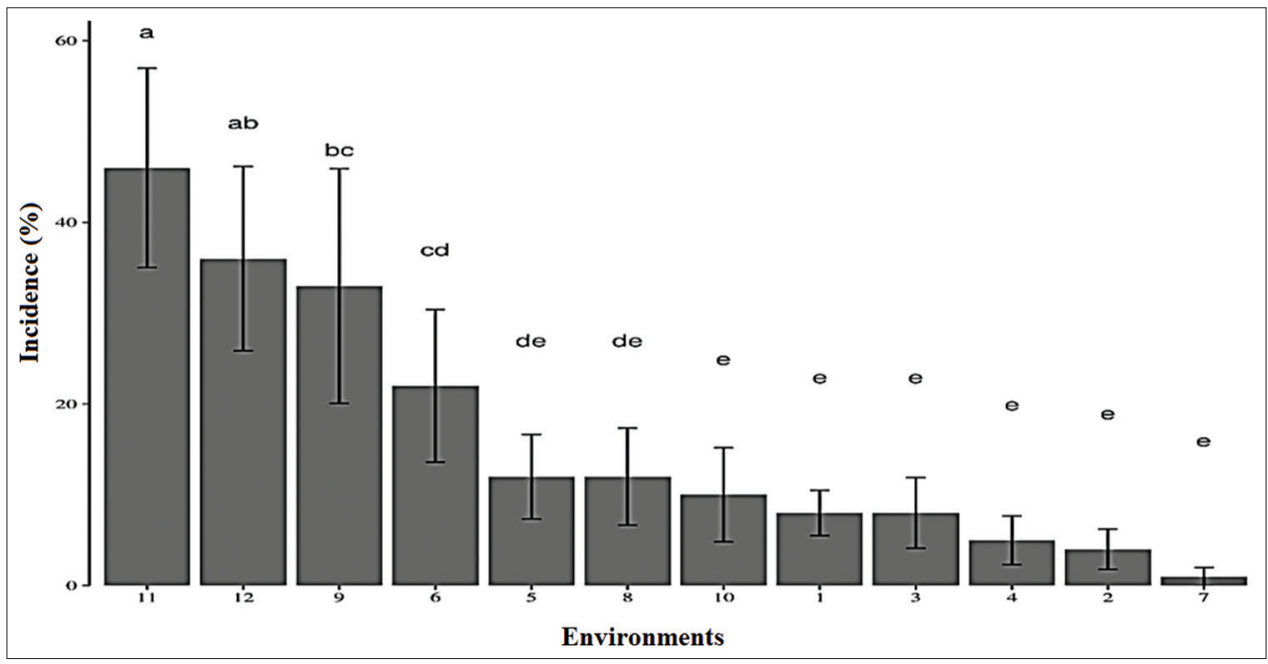

Figure 2: Incidence of fungi in sotol seeds in 12 storage environments, according to Tukey at 0.05 , groups with different letters are statistically significant 
with $30.8 \%$ and finally, in sampling at 90 days with $34.5 \%$ (higter incidence).

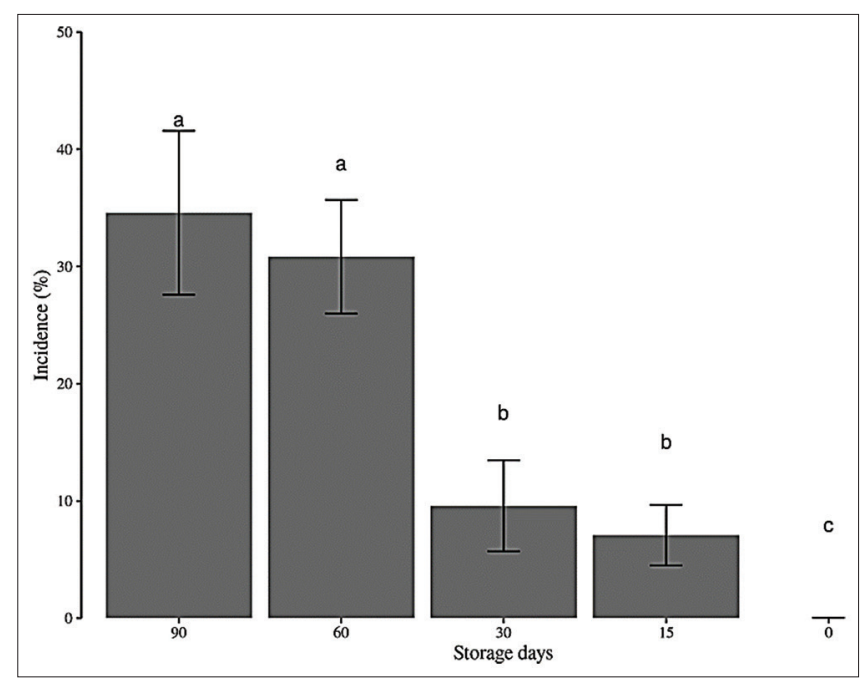

Figure 3: Incidence of fungi in sotol seeds at four storage periods, according to Tukey at 0.05 , groups with different letters are statistically significant
Analysis of samples at day 0 presented no detectable pathogens, after a 15-day period of storage fungi was first detected: A. glaucus, A. niger, Fusarium sp. and Penicillium sp. with an incidence of $35,5,10,5$ and $5 \%$ in the environments $3,6,10$, 11 and 12, respectively. Next, after a 30-day period A. glaucus, Penicillium sp., and A. niger were detected in 5 to $20 \%$ of the environments, namely $1,4,10$ and 12 . At day 60 , A. glaucus was predominant in 30 to $75 \%$ of the environments $(3,5,8$, 9, 11 and 12) in addition to Penicillium sp., Aspergillus candidus, Cladosporium sp., Alternaria sp. and Fusarium sp. (4 to 10\%) in the 4, 5, 6 and 9 environments. Finally, after 90 days A. glaucus was the predominant pathogen ranging from 5 to $85 \%$ of the environments (1, 5, 8, 9, 10, 11 and 12). A. ochraceus, Penicillium sp. and Fusarium sp. were the least detected fungi ( 5 to $20 \%$ ) in the environments 3, 4, 5, 9 and 11 (Figure 4). In 2001 isolated nine fungal species from different varieties of Arachis hypogaea seeds during a year in storage (Vikas \& Mishra, 2010).

\section{DISCUSSION}

Environment 12 had the highest presence of fungi (relative humidity of $85 \%$ kept at $25^{\circ} \mathrm{C}$ ), followed by environments 3 , 5, 9, 10 and 11 with Aspergillus spp. being the predominant

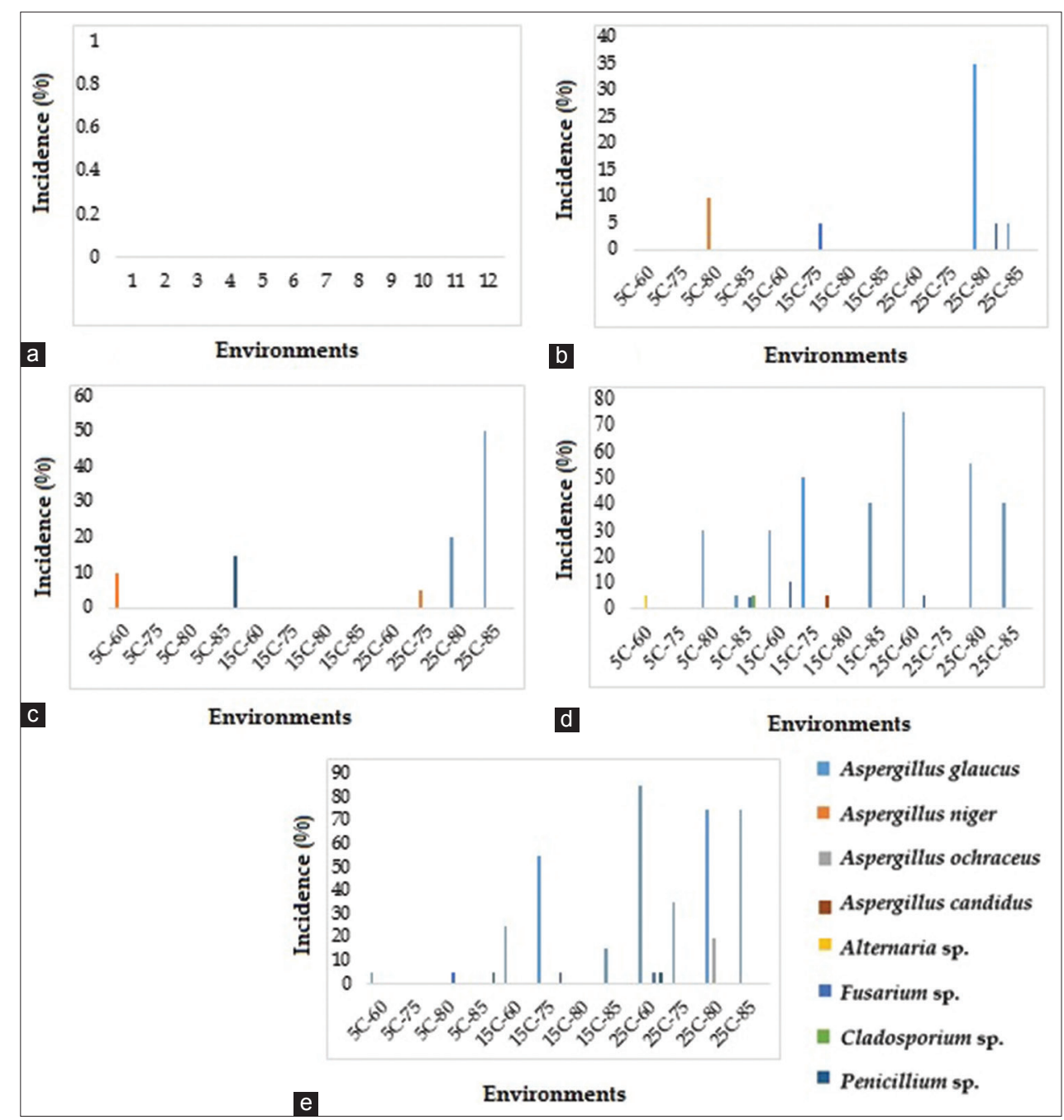

Figure 4: Incidence of fungi at different storage periods. $a=0$ day, $b=15$ days, $c=30$ days, $d=60$ days and $e=90$ days 
genus, followed by Penicillium spp., Aspergillus and Penicillium, are the main pathogens found in stored seeds (Mercado \& Precios, 2020), results that agree whit various authors (Montes et al., 2009; Pabón-Villalobos \& Castaño-Zapata, 2012; Tsedaley \& Adugna, 2016; Bhalerao \& Chavan, 2017)). Humidity and temperature are the main variables that affect pathogen activity, in storage conditions at higher temperature and humidity microbial proliferation is enhanced (Chulze, 2010; Hell et al., 2010; Martinez et al., 2010), results similar to those obtained in the present research. Best storage conditions are obtained in cool and dry climates, as well these allow grain longevity for a reasonable time (Suleiman et al., 2013).

Other important factor is the control of pest insects; fungi is second after insects as the cause of deterioration and loss of maize (Uzma \& Shahida, 2007; Popp et al., 2013), although postharvest losses in maize due to storage insect pests are generally estimated to range between 20 to 30\% (Boxall, 2002), for example, he maize weevil (Sitophilus zeamais), and larger grain borer (LGB) (Prostephanus truncatus) are the major pests in the maize. About 23\% losses were observed in maize grains stored for six months, mainly due to infestation of maize weevil and LGB in Benin (Meikle et al., 2002; Kimenju \& de Groote, 2010). As the population of insects increases, more heat and humidity will be produced, favoring the development of fungi that affects the grains (Abdullahi et al., 2014).

Blancas (2007) mentioned that fungi Aspergillus genus are the more common contaminants in stored seeds, since they are better adapted to environmental conditions in which seeds are generally stored. Warehouse fungi that infects seeds or grains during storage are: A. restrictum, A. glaucus, A. candidus, Penicillium spp. needing a relative humidity in the range of $70-90 \%$ at $25-35^{\circ} \mathrm{C}$. Similar environmental conditions as the ones in the 10, 11 and 12 environments, that reported higher presence of pathogens. The most clinically important fungi for humans and animals are: Fusarium spp., Aspergillus spp. and Penicillium spp. In addition, these can develop on a wide range of stored grains and corn seeds (Tola et al., 2016). Said fungi constitute a health hazards that can affect different cereals and their derived products. Fungi like Aspergillus niger, Aspergillus flavus, Alternaria dianthicola, cause discoloration, rotting, shrinking, necrosis, loss in germination capacity and toxification in oil seeds (Kakde \& Chavan, 2011).Thus the use of certified seeds (pathogen-free) is important (Peralta et al., 2009). Conditions with higher relative humidity and temperature favors the presence of fungi that cause deterioration. Fungi with higher presence in sotol seeds were: Aspergillus glaucus and Penicillium sp. Safe storage environments for sotol seeds reported in this work are $5^{\circ} \mathrm{C}$ and a relative humidity of 60 $75 \%$. Sotol seeds tolerates conditions of $15^{\circ} \mathrm{C}$ and a relative humidity up to $75 \%$.

\section{ACKNOWLEDGEMENTS}

The authors would like to thank the Universidad Autonoma Agraria Antonio Narro, and the people of Buñuelos, municipality.

\section{REFERENCES}

Abdullah, S. K., \& Al-Mousawi, K. A. (2010). Fungi associated with sunflower (Helianthus annuus L.) cultivars grown in Iraq. Phytopathologia, 57, 11-20.

Abdullahi, N., Umar, I., Tukur, Z., \& Babura, S. R. (2014). Comparative efficacy of the bark and root powders of Acacia nilotica against maize weevil Sitophilus zeamais (Motsculsky) (Coleoptera: Curculionidae) in Kano State of Nigeria. African Journal of Agricultural Research, 9 (6), 588-592. https://doi.org/10.5897/AJAR2012.1131

Amaral, F. V., \& Lemos, M. N. (2009). O potencial do armazenamento de cada semente. Seed News. Retrieved from https://seednews.com. br/artigos/1804-o-potencial-de-armazenamento-de-cada-sementeedicao-julho-2009

Bhalerao, V., \& Chavan, A. (2017). Isolation of filamentous fungi in postharvest cereal grain during the storage and their effect on seed health. International Journal of Advanced Research, 5 (8), 2171-2177. https://doi.org/10.21474/IJAR01/5283

Blancas, M. B. (2007). Manejo de granos en almacenamiento, causas de deterioro y prevención.ano State of Nigeria. African Journal of Agricultural Research, 9 (6), 588-592.

Boxall, R. A. (2002). Damage and loss caused by the larger grain borer Prostephanus truncatus. Integrated Pest Management Reviews, 7 , 105-121. https://doi.org/10.1023/A:1026397115946

Castlellarie, C., Valle, M. F., Mutti, J., Cardoso, L., \& Bartosik, R. (2010). Toxigenic fungi in Corn (maize) stored in hermetic plastic bags. $10^{\text {th }}$ International Working Conference on Stored Product Protection, 425, 501-504. https://doi.org/10.5073/jka.2010.425.323

Chavan, A. M. (2011). Nutritional changes in oilseeds due to Aspergillus spp. Journal of Experimental Sciences, 2, 29-31.

Chulze, S. N. (2010). Strategies to reduce mycotoxin levels in maize during storage: a review. Food additives \& contaminants: Part A, 27 (5), 651-657. https://doi.org/10.1080/19440040903573032

Hell, K., Ognakossan, K. E., Tonou, A. K., Lamboni, Y., Adabe, K. E., \& Coulibaly, O. (2010). Maize Stored Pests Control by PICS-Bags: Technological and Economic Evaluation. $5^{\text {th }}$ World Cowpea Conference in Saly, Senegal (27 September -1 October 2010). https:// doi.org/10.13140/RG.2.1.4207.5289

Kakde, R. B., \& Chavan, A. M. (2011). Extracellular lipase enzyme production by seed-borne fungi under the influenc of physical factors. International Journal of Biology, 3 (1), 94-100. https://doi. org/10.5539/ijb.v3n1p94

Kimenju, S. C., \& de Groote, H. (2010). Economic analysis of alternative maize storage technologies in Kenya; Proceedings of the Joint $3^{\text {rd }}$ African Association of Agricultural Economists (AAAE) and $48^{\text {th }}$ Agricultural Economists Association of South Africa (AEASA) Conference (19-23 September 2010); Cape Town, South Africa. https://doi.org/10.22004/ag.econ.96419

Martínez, M., Moschini, R., Barreto, D., Bodega, J., Comercio, R. Forjan, H., Piatti, F., Presello, D., \& Valentinuz, O. (2010). Factores ambientales que afectan el contenido de fumonisina en granos de maíz. Tropical Plant Pathology, 35(5), 277-284. https://doi. org/10.1590/S1982-56762010000500002

Meikle, W. G., Markham, R. H., Nansen, C., Holst, N., Degbey, P., Azoma, K., \& Korie, S. (2002). Pest management in traditional maize stores in West Africa: A farmer's perspective. Journal of Economic Entomology, 95(5), 1079-1088. https://doi.org/1079-88. 10.1093/ jee/95.5.1079

Mercado, A. D., \& Precios, A. C. (2020). Almacenamiento en México. Claridades Agropecuarias.

Mercado, C. G. E. (2018). Importancia de la patología de semillas en el almacenamiento de granos. INTA.

Montes, G. N., Reyes, M. C. A., Montes, R. N., \& Cantu, A. M. A. (2009). Incidence of potentially toxigenic fungi in maize (Zea mays L.) grain used as food and animal feed. CYTA - Journal of Food, 7 (2), 119-125. https://doi.org/10.1080/19476330902940432

Moreno E. (1988). Manual para la identificación de hongos de granos y sus derivados. UNAM. México, DF. 109.

Oyekale, K. O., Daniel, I. O., Ajala, M. O., \& Sanni, L. O. (2012). Potential longevity of maize seeds under storage in humid tropical seed stores. Nature and Science, 10 (8), 114-124.

Pabón-Villalobos, J., \& Castaño-Zapata, J. (2012). Identificación de hongos y bacterias en granos de arveja (Pisum sativum Linneo). Agronomía, 20 (1), 26-37. 
Peralta, I., Murillo, I., \& Mazón, N. (2009). Producción y distribución de semilla de buena calidad de fréjol arbustivo con pequeños agricultores, a través de un sistema no convencional (Artesanal). 57.

Poehlman, J. (2005). Mejoramiento genético de las cosechas. Limusa. México. 257.

Popp, J., Pető, K., \& Nagy, P. (2013). Pesticide productivity and food security. A review. Agronomy for Sustainable Development, 33, 243-255. https://doi.org/10.1007/s13593-012-0105-x

R Core Team (2013). R: A language and environment for statistical computing. R Foundation for Statistical Computing, Vienna, Austria.

Reyes, M. H., Benavides, A., Ramirez, H., \& Villarreal, J. A. (2012). Biología E Importancia del Sotol (Dasylirion spp.). Parte I: Sistemática, Genética y Reproducción. Planta, 14, 11-13.

Suleiman, R., Rashid, K. A., Rosentrater, \& Bern, C. (2013). Effects of Deterioration Parameters on Storage of Maize: A Review. Wuhan University Journal of Natural Sciences, 3, 147-165. https://doi. org/10.13031/aim.20131593351

Tola, M., \& Kebede, B. (2016). Occurrence, importance and control of mycotoxins: A review. Cogent Food \& Agriculture, 2(1), 1191103 https://doi.org/10.1080/23311932.2016.1191103

Tsedaley, B., \& Adugna, G. (2016). Detection of fungi infecting maize (Zea mays L.) seeds in different storages around Jimma, Southwestern Ethiopia. Journal of Plant Pathology and Microbiology, 7, 338. https:// doi.org/10.4172/2157-7471.1000338

Uzma, S., \& Shahida, A. (2007). The screening of seven medicinal plants for artificial activity against seed borne fungi of maize seeds. Pakistan Journal of Botany, 39, 285-292.

Valdés, R., Mendoza, B., Rodríguez, R., \& Quintanilla, V. (2012). Biología e Importancia del Sotol (Dasylirion spp). Parte I: sistemática, genética y reproducción. Planta, 14 (7), 11-13.

Vikas, P.V., \& Mishra, U.S. (2010). Efecto de la temperatura sobre la dinámica de los hongos de almacenamiento de semillas oleaginosas. Journal of Plant Research, 23, 9-14.

Winston, P. W., \& Bates, D. H. (1960). Soluciones saturadas para el control de la humedad en la investigación biológica. Ecología, 41, 232-237. 